\title{
A Five-Wave Model Evolution of Philippine Piano Music Literature
}

\author{
Han Yaqin \\ College of Music, Shanxi University, Taiyuan, China
}

\begin{abstract}
Keywords: Philippine Piano Music, Filipino composer, Indigenous songs, Waves of Stylistic Development
\end{abstract}

Abstract: The purpose of this research is to learn about the development of Philippine piano music literature from its inception.

\section{Introduction}

Music and dancing have always been important in the earliest Philippine cultures. Even now, Filipinos like to describe themselves as "very musical." To grasp the essence of Philippine piano music, one must first grasp its composers' historical and cultural backgrounds: four centuries of colonial power that left a distinctively European mark on the Philippine musical psych.

From fables and primordial stories to serious works on socio-political themes, Philippine literature has progressed over the ages. When it comes to the development of Hispanic writing systems and the merging of diverse languages in search of perfection, the transition has played an important role. Before the arrival of the Spaniards, the literature of the Philippines was mostly a reflection of the indigenous culture and customs of the area. The residents of Manila, as well as indigenous populations across the Philippines, used to write on bamboo and arecaceae palm leaves. They inscribed the old Tagalog script using knives, which they found in a cave. The literature that was kept consisted of of the seventeen fundamental symbols of the language that had been retained. In its 'raw' condition, the literature passed down had just three vowels and consonantal symbols with a preset, inherent sound. This literature needed to be developed and refined.

Articles about the Spanish conquest, indigenous cultural history, pre-colonial literature, and traditional storytelling are among the literary works that are presently accessible. Inspiring speeches and songs are a highly fascinating area of Philippine literature that should not be missed. This chapter has done an excellent job of preserving the mysterious quality of Philippine epics and folk tales in modern times. The tales and depictions of numerous magical persons, mythological artifacts, and the supernatural are fantastical, yet they are firmly rooted in the ideas and practices of the indigenous people of the world.

As numerous academics have pointed out, the Philippines already had a thriving literary culture, both written and oral, even before the arrival of the Spaniards, which has survived to the present day. Nevertheless, due to factors such as the impermanence of the leaves and barks used by the natives for writing, their burning by the Spanish friars, the introduction of the printing press and the Roman alphabet, which replaced the native syllabary and the latter's unsuitability for recording long passages, only a few written pre-colonial literary works have survived to the present day. In part as a 
result, ethnic cultural minority who have never been colonized and so serve as windows into the past are the primary sources of information about indigenous literature in the modern period. It is the type of thing that is committed to memory and passed down from generation to generation by word of mouth.

Tribal chiefs and elders were removed from their customary positions when the Spaniards arrived, and they were relegated to the status of 'folk people' in colonial society. In the end, some of them were co-opted by the colonial government to form a new class of local rulers to aid in the pacification and administration of the natives, but others were left to continue passing on the mythology and epics of their traditional heroes, who served as role models for the next generation of natives. As a consequence of the beginning of colonization, the topics of these heroic tales, in contrast to myths, represented the ideals and beliefs of this rising elite of new rulers, underlining their increasing distance from and power over the local people.

Last but not least, the folk tales generated by the populace constitute the third kind of indigenous literature. Their thoughts, attitude, and life objectives are all expressed via their tales. This genre includes tales that satirize persons in positions of authority in a lighthearted manner, as well as riddles, proverbs, and aphorisms that proclaim self-evident facts in a didactic-moralistic tone. The collective knowledge of the community is passed on via each of them in order to maintain the harmonious functioning and reproduction of the community.

\section{Background of the study}

The acceptance of liberal democracy as the new way of life in the Philippines would result in a battle between traditional Filipino traditions and the new form of government. Individuals began to realign themselves along the lines of a genuine class consciousness, which emphasized the elite while supporting the emergence of a class of professionals, as the social structure began to shift. At the same time, the new democratic administration was able to keep the public somewhat content by providing them with some measure of socioeconomic progress.

Because of the advent of western activities, which found a unique position in Filipino society, there has been a rapid shift in the country's culture. Philippines were forced to conform to the American regime's veneer of novelty, which was accentuated by the imposition of a new system and the use of the English language. As a result of the popularity of fox-trots and two-steps, the government modified the age of religious music to fit with the time period. In 1916, the Filipinos were promised independence in return for the establishment of a stable administration in the country. It was in 1934 that the United States became the first country to fully cede responsibility over a colony, after more than a decade of tutelage. The Philippines became a United States Commonwealth (a self-governing state that chooses to be associated with the United States).

When American imperialism attempted to re-create her notions of democratic self-rule in the Philippines and turn the country into a real democracy, the idealistic spirit of the United States was visible. A small number of the war-damaged institutions were reconstructed, and the establishment of the University of the Philippines in 1908 opened the door to higher education for the first time. Some established institutions maintained the use of Spanish as a language of teaching, but competitive pressure pushed them to discontinue the use of Spanish and replace it with English. English became the standard language of teaching in all schools, colleges, and other institutions as a result of this development. More over $40 \%$ of the population speaks English well, making the Philippines the world's third-largest English-speaking nation after the United States and Great Britain.

In contrast to Europe and the United States, where concert pianists have a more promising future, pianists in the Philippines sometimes play for no fee or for a small donation. Being able to make a consistent living by teaching piano and music theory provided a platform for networking other 
Filipino artists. Spanish colonists brought Western music to the Philippines as early as the 16th century, and it has been there ever since. Various religious organizations were tasked with spreading Catholicism across the archipelago, which resulted in the conversion of the great majority of the indigenous population. The importance of music in drawing the early Filipino Christians to the Church's ceremonial practices cannot be overstated. As a result of this training process, the local musicians and composers who would go on to develop the traditions of distinctly "Philippine" music were also created.

\section{Hypothesis}

Philippine piano music has had a significant influence on Philippine literature. The Philippine piano teaching style blends Western and local traditions. It seems to come from the same contemporary nationalist tradition, and his most recent piano pieces are heavily influenced by indigenous rhythms and sonorities.

\section{Review of Related Literature And Studies}

After opening to international commerce in 1834, the Philippines saw enormous socioeconomic gains as a result of liberalization. The industrialization of Philippine agriculture and subsequent economic growth created a rich local elite. The Suez Canal opened in 1869, allowing wealthy Filipinos to study in Europe. The propaganda movement began as a consequence of liberal views teaching national liberty. Many Filipino nationalists called the situation "la soberana monacal," referring to the church's overpowering power (frairocracy).

The friars reigned over kingdoms and influenced politics. Because of this, the most heinous atrocities were perpetrated, culminating in the Philippine Revolution (1896-1898). Cuba and Puerto Rico had colonial uprisings against Spain at the same time. After Spanish soldiers sank a US naval ship in Havana Harbor in February 1898, the US declared war on Spain. In 1898, Spain wanted peace after losing both wars in Cuba and the Philippines.

The US got most of the Spanish colonies, including Guam, Puerto Rico, Cuba, and the Philippines, for \$20 million. The new colonists brought with them an economic structure that allowed them full access to the country's resources. The Spanish feudal system was not abolished; in fact, the US occupation increased tenancy due to a land registration system favored by the top Filipino classes. The emergence of American liberal democracy as the new norm in the Philippines would result in a clash of cultures (Santos, 1995).

Socially, a new middle class of professionals emerged, with the masses pleased with some socioeconomic gains from the new democratic government. The influx of western activities has resulted in a rapid cultural shift. The new system and the English language forced Filipinos to adapt to the American regime's novelty. The government also modified the religious music age to match the foxtrot and two-step craze.

Independence was promised to the Filipinos in 1916. After more than a decade of tutelage, the United States freed a colony in 1934. 8 The Philippines joined the United States Commonwealth (a self-governing state voluntarily linked to the US), as the US sought to grow commerce in Asia and influence Pacific power politics. The desire of American imperialism to replicate her democratic self-rule principles in the Philippines and transform a country into a real democracy was clear. Some war-damaged institutions were rebuilt, and the University of the Philippines was formed in 1908. However, competition led several established institutions to forsake Spanish in favor of English. As a result, all schools, colleges, and institutions now teach in English. It has the world's third biggest English-speaking population, with over 40\% fluent in English.

Because music is so important to a nation's cultural identity, it deserves special consideration. This 
conversation may help you comprehend today's Filipino songwriters' motivations. Pre-Spanish Filipinos' main religious beliefs were centered on a hierarchy of deities and spirits. These spirits might be good or bad depending on how one interacts with them everyday. These rites dealt with the crop, the weather, and other vital aspects of man's existence. Filipinos engaged with ghosts like they did with the living. These spirits would get angered and create disease if not respected.

Rituals and séances must please the spirits. These Filipino traditions predated Spanish colonization. 1 The Spanish colonized the Philippines in 1565. Every Spanish expedition featured a group of missionaries tasked with evangelizing the natives. Conversion meant acquiring a new set of religious beliefs while rejecting the whole culture that backed them. Spanish colonial rule changed the face of Philippine culture in general and music in particular. Epic hero songs and native drum and gong rhythms started to diminish in favor of Christian church hymns and organ, harp, and guitar harmonies.

To convert people to Christianity, the Spanish King's missionaries initially tried to remove images and noises of ancient rituals. Indigenous music performance was discouraged. Only a few texts have survived in modified form. Native ceremonial music was combined with contemporary religious music, resulting in several indigenous secular genres influenced by Spanish secular music. Its diatonic melodies and chordal accompaniments reflected Western melody and harmonic progression.

\section{Five Waves Model of Philippine Piano Music}

The unpretentious attractiveness of Adonay's salon works, which were indistinguishable from their European equivalents, epitomized the initial wave. During the second wave, nationalism fostered the demand for a national identity in music. Some of Buencamino's piano work resembled Chopin and Liszt in motion and keyboard technique, but it also included danza, tango, and habanera components.

In the third and fourth waves, the modern automation of travel permitted Filipinos to study music abroad. Composers in the Philippines found fresh inspiration in their country's long-ignored pre-Hispanic traditions and connections with other Asian nations. Globalization offers a way out of the deadlock of nationalism and even "pan-Asian" ideology by opening up a vast field for compositional inquiry that transcends all cultural and historical boundaries.

\begin{tabular}{|c|c|c|c|c|}
\hline First Wave & Second Wave & Third Wave & Fourth Wave & Fifth Wave \\
\hline $\begin{array}{l}\text { Marcelo Adonay } \\
(1848-1926)\end{array}$ & $\begin{array}{l}\text { Francisco } \\
\text { Buencamino, Sr. } \\
(1883-1952) \\
\text { Francisco } \\
\text { Santiago } \\
(1889-1947) \\
\text { Nicanor } \\
\text { Abelardo } \\
(1893-1934)\end{array}$ & $\begin{array}{l}\text { Lucrecia Kasilag } \\
\text { (1917-2008) } \\
\text { Jose M. Maceda } \\
\text { (1917-2004) }\end{array}$ & $\begin{array}{l}\text { Ramon P. Santos } \\
\text { (b. 1941) } \\
\text { Josefino Toledo } \\
\text { (b. 1964) }\end{array}$ & $\begin{array}{l}\text { Jeffrey Ching (b. } \\
1965)\end{array}$ \\
\hline
\end{tabular}

Figure 1 Five Waves Model of Philippine Piano Music 


\section{Conclusions}

An ethnic and cultural mash-up, the Philippines was both Oriental and Occidental in the second part of the twentieth century. Pre-modern Philippine artists expressed their national goals via music, first as mimics of European civilisation, later as rebels against Western colonization.

Adonay's naïve simplicity gave way to the rising complexity of Filipino composers whose compositions reflected more than just one or more prevailing European forms, but also a growing social and political unrest. First Asian attempts to express national identity via music, particularly by infusing local folk material into Western forms and idioms, developed parallel to Glinka and Smetana's musical nationalism in Europe.

\section{References}

[1] Agoncillo, Teodoro A. and M. C. Guerrero. History of the Filipino people. R. P. Garcia. Quezon City: Publishing Company, 1973.

[2] Berger, Kenneth. "Filipino Musicians,” Unpublished typewritten biographical compilation and alphabetical listing of Filipino musicians. Evansville, Indiana, 1948.

[3] Echols, John M. The background of literature in Southeast Asia. Six Perspectives on the Philippines. Manila: Bookmark, Inc., 1971

[4] Eugenio, Damiana L. Philippine Folk Literature. Quezon City: The University of the Philippines Folklorists Inc, 1982.

[5] Maceda, Jose M. "Music in the Philippines in the Nineteenth-century" in Musikkulturen Asiens und Afrikas im 19. Jahrhunderts. Regesburg: Gustav Bosse, 1973.

[6] Santos, Ramon P. Constructing a National Identity through Music. Journal of Philippine Arts and Culture, 2001 p. 21-31. The music of Asean. Manila: General ed. 1995.

[7] Quirino, C. (1995). Who's who in Philippine history. Manila: Tahanan Books.

[8] Tiongson, N. (Ed.) (1994). CCP encyclopedia of Philippine Art (Vol. 6: Philippine music). Manila: Cultural Center of the Philippines 